\title{
Öğretmen Adaylarının Öğretmenlik Mesleğine İlişkin Tutumlarının Bazı Değişkenler Açısından İncelenmesi
}

\author{
Mustafa Durmuşçelebi ${ }^{*}$ Nihan Y1ld1z ${ }^{* *}$ - Ezgi Saygi ${ }^{* * *}$ \\ * Doç. Dr., Erciyes Üniversitesi, Eğitim Fakültesi, Melikgazi/Kayseri/ Türkiye \\ E-Posta: mcelebi@erciyes.edu.trＯORCID: 0000-0002-0325-7528 \\ ** Öğretmen, Şehit Üsteğmen Mustafa Şimşek Ortaokulu, Kocasinan / Kayseri / Türkiye \\ E-Posta: nhnyldz07@gmail.com ORCID: 0000-0002-0942-1704 \\ *** Öğretmen, Mustafa Kemal Ortaokulu, Melikgazi / Kayseri / Türkiye \\ E-Posta: ezgi.sglm@hotmail.com ORCID: 0000-0001-5247-4206
}

Öz

Öğretmen yetiştirme konusu eğitim biliminin en önemli işlevlerinden birisidir. Öğgretmen eğitimi üç temel üzerine planlanmıştır: alan bilgisi, genel kültür ve öğretmenlik formasyonu. Ancak her şeyden önce öğretmen olacak kimsenin mesleği sevmesi, içselleştirmesi, ona saygı duyması ve mesleğin gerektirdiğgi olmazsa olmaz becerilere sahip olması gerekir. Bu araştırmanın amacı cinsiyet, yaş, öğrencilerin geldikleri üniversite, okudukları bölüm, mezun olup olmamalar, ailelerinin meslekleri gibi değişkenleri ve 35 maddeden oluşan öğretmenlik mesleğine ilişkin tutumları üç boyutta (sevgi, değer, uyum) ele alan Çetin (2006) tarafindan geliştirilen "Öğretmenlik Mesleği Tutum Ölçeğgi" ölçeği aracıllı̆̆ ile eğitim fakülteleri dişından gelen öğretmen adaylarının öğretmenlik mesleğine ilişkin tutumların belirlemektir. Araştırmanın örneklem grubunu Türkiye'nin değişik kentlerinde bulunan toplam 28 üniversitenin değiş̧ik fakültelerinin 15 bölümünden 558 öğrenci oluşturmaktadır. Yapılan istatistiksel analizlerde öğrenci tutumlarının çeşitli değişkenlerde farklılaştığı saptanmıştır.

Anahtar Kelimeler: Pedagojik Formasyon, Tutum, Öğretmenlik Mesleği

OPUS (c) Uluslararası Toplum Araştırmaları Dergisi-International Journal of Society Researches ISSN:2528-9527 E-ISSN : 2528-9535

http://opusjournal.net 


\title{
Investigation of Teacher Candidates' Attitudes towards Teaching Profession
}

\begin{abstract}
The matter of teacher training is one of the most important functions of pedagogy. Teacher training has been planned on three bases: field information, general knowledge and teaching formation. However, first of all it is a must that the person who will be a teacher loves his/her occupation, internalizes and respects it, and has necessary skills for the profession. The aim of this research is to determine pedagogical formation program students' attitudes towards teaching profession through "The Teaching Profession Attitude Scale" developed by Çetin (2006) discussing variables in three dimensions (love, esteem, adaptation) such as gender, age, university students graduate from, field they study in, whether they have graduated or not, and profession of their parents and discussing attitudes consisting of 35 items related to teaching profession. 558 students from 15 departments of various faculties in a total of 28 universities have formed the sample of the research. It has been determined after statistical analysis that students' attitudes differentiate according to different variables.
\end{abstract}

Anahtar Kelimeler: Pedagogical Formation, Attitude, Teaching Profession

OPUS (c) Uluslararası Toplum Araştırmaları Dergisi-International Journal of Society Researches ISSN:2528-9527 E-ISSN : 2528-9535

http://opusjournal.net 


\section{Giriş}

Öğretmenlik bir ülkede toplumun, yeni nesillerin, bilimin, teknolojinin kısaca topyekûn sağlıklı bir gelişmenin temel unsurudur. Söz konusu gelişimi sağlamak amacıyla gereksinim duyulan insan gücünü öğretmenler yetiştirmektedir. Bilim insanları öğretmenlerin toplumdaki değişmeye liderlik ettiğini ve bu nedenle öğretmenlerin mesleki gelişim davranışlarının diğer mesleklere nazaran daha önemli olduğunu vurgulamaktadır (Cobb, 1999; Harris, 2000). Bu yüzden toplumun gelişmesi, sistemin başarıya ulaşması, nitelikli insan gücü ancak ve ancak nitelikli öğretmen yetiştirmekle mümkün olabilir.

Bir eğitim sisteminin başarısı okul, öğretmen, öğrenci ve eğitim programları öğeleri ile ilgilidir. Bu öğelerin tümünün görevlerini doğru bir şekilde yerine getirmesi eğitim sisteminin başarılı olmasını sağlar (Katkat ve Mızrak, 2003). Eğitim sisteminde öğretmenin önemi, öğrenci ve eğitim programlarının öneminden daha yüksektir (Karagözoğlu, 1987).

Osmanlı' da öğretmen yetiştirme uygulamaları, Rüştiyelerin öğretmen gereksinimini karşılamak amacıyla 16 Mart 1848 tarihinde Dar-ül Muallimin-i Rüşti (İlk Öğretmen okulu) açılmasıyla birlikte başlamış olup yaklaşık 167 yıllık bir deneyime sahiptir. Cumhuriyet'in kurulması ile birlikte üzerinde en çok değişiklik yapılan sistemin öğretmen yetiştirme deneyimleri olduğu söylenebilir. Son 20 yılda yapılan değişikliklerden biri olarak Yüksek Öğretim Kurumu (YÖK), MEB ve Dünya Bankası projelendirme çalışmaları kapsamında 1997'de yapılmış ve 1998-99 eğitim öğretim yılında uygulanmaya konmuştur (Kavcar, 2002). Bu uygulamanın Milli Eğitime yansıması 8 yıllık ilköğretim şeklinde olmuştur. Bu tarihe kadar hiçbir önkoşul ortaya konmadan çok farklı alanlarda lisans mezunu herkes öğretmen olabiliyordu. Bu açıdan düşünüldüğünde sistemin acil bir değişikliğe gereksinimi vardı. Bu düzenleme ile tüm öğretmenlik programları Eğitim Fakülteleri bünyesinde toplanmıştır. Ancak bir süre sonda bu uygulamadan da vazgeçilerek, söz konusu bölümler ilgili fakülte ve yüksekokullara dönmüşlerdir.

Eğitim fakültelerinde uygulanan program kapsamında ilköğretim öğretmenliği ve ortaöğretim alan öğretmenliği programları uygulanmaya başlanmıştır. Söz konusu bu uygulamalar da zamanla YÖK ve Milli Eğitim Bakanlığ1 (MEB) ile Eğitim Fakülteleri ve Fen Edebiyat Fakülteleri 
arasında gerekli işbirliğinin yapılmaması sonucu oldukça fazla yanlış uygulamalara, eleştirilere, görev karmaşasına ve hatta Eğitim Fakülteleri içinde Fen-Edebiyat fakültesi yapılanmalarına neden olmuştur. 1997'de yapılan düzenlemelerle programlarda yer alan derslerin düzenlemelerinde de değişikliklere gidilmiştir. Örneğin Psikoloji, sosyoloji, felsefe, eğitim psikolojisi, eğitim tarihi gibi dersler programda yer almamıştır (Yüksek Öğretim Kurumu [YÖK], 1998). Öğretmenliğin özellikle genel kültür boyutuyla ilgili olan bu derslerin programda yer almaması eleştirilebilecek uygulamalar arasında yer almaktadır.

Öğretmen yetiştirme sisteminde 2006 yılından sonra yapılan değişikliklerle, öğretmen adaylarının genel kültür dersleri artırılmış ve seçmeli ders olanakları artırılmıştır. Bunun sonucunda da öğretmenler farklı becerilere sahip olarak mezun olabilmişlerdir. Bunların yanı sıra uygulama ders saatleri azaltılmış, özellikle fen ve edebiyat fakülteleri öğrencileri tarafından kullanılan 3,5+1,5 sistemi kaldırılarak, meslek bilgisi dersleri sürece yayılmıştır. Son olarak 2010 yılında YÖK tarafından yeni bir düzenleme yapılmış ve hâlihazırda bu uygulama devam etmektedir. Söz konusu uygulamaya göre, eğitim fakültelerinden ve başta fen-edebiyat fakülteleri olmak üzere çok sayıda fakülteden mezun olup pedagojik formasyon eğitimini başarı ile tamamlayan öğrenciler öğretmen olarak görev yapabilme hakkına sahip olmuşlardır. Bu uygulama da beraberinde, "Formasyon eğitimi öğretmenlik yeterliklerini kazanabilmek ne kadar için etkili olabilir?" tartışmasını getirmiştir.

Öğretmen yetiştirme konusu eğitim biliminin en önemli işlevlerinden birisidir. Öğretmen eğitimi üç temel üzerine planlanmıştır: alan bilgisi, genel kültür ve öğretmenlik formasyonu. Ancak her şeyden önce öğretmen olacak kimsenin mesleği sevmesi, içselleştirmesi, ona saygı duyması ve mesleğin gerektirdiği olmazsa olmaz becerilere sahip olması gerekir. Bu araştırmanın amacı, eğitim fakültelerinde formasyon eğitimi alan öğretmen adaylarının öğretmenlik mesleğine ilişkin tutumlarını belirlemek ve söz konusu tutumlarını bazı değişkenler açısından incelemektir.

$\mathrm{Bu}$ amaç doğrultusunda araştırmada aşağıdaki sorulara cevap aranmiştır:

1. Öğretmen adaylarının öğretmenlik mesleğine ilişkin tutumları nasıldir?

2. Öğretmen adaylarının öğretmenlik mesleğine ilişkin tutumları; 

a. Cinsiyetlerine,
b. Yaşlarına,
c. Geldikleri üniversiteye,
d. Okudukları bölüme,
e. Mezun olup olmamalarina,
f. Babalarının mesleklerine,
g. Annelerinin mesleklerine,
h. Aile tiplerine ve
i. Ailelerinde öğretmen olup olmamasına göre değişmekte mi- dir?

3. Öğretmen adaylarının öğretmenlik mesleğinin sevgi, değer ve uyum boyutlarına ilişkin tutumları arasında anlamlı bir fark var mıdır?

\section{Yöntem}

Bu bölümde araştırmanın modeli, evren ve örneklem, verilerin toplanması ve çözümlenmesine yer verilmektedir.

\section{Araştırmanın modeli}

Eğitim fakültelerinde formasyon eğitimi alan öğretmen adaylarının öğretmenlik mesleğine ilişkin tutumlarını betimlemeye yönelik yapılan bu çalışma tarama yöntemiyle yapılan bir araştırmadır. Yapılan bu çalışmada öğretmen adaylarının mesleği sevme, değer verme ve uyum sağlama boyutlarındaki tutumları betimlenmeye çalışılmıştır.

\section{Evren ve örneklem}

Araştırmanın evrenini Erciyes Üniversitesi Eğitim Fakültesinde 2015-2016 eğitim öğretim yılında yürütülen formasyon programına katılan öğrenciler oluşturmaktadır. Çalışmanın örneklem grubunu ise, yaklaşık 2000 civarında öğrenci içerisinden tesadüfi örnekleme yöntemiyle seçilen, 28 farklı üniversitenin 15 değişik bölümünden mezun ya da mezun durumunda olan toplam 558 öğrenciyi kapsamaktadır. Üniversiteler daha sonra araştırma amacı doğrultusunda uygun istatistikler yapabilmek 
amacıyla dört başlık altında toplanmıştır. Kayseri'de bulunan biri özel, birisi devlet olmak koşuluyla iki, öğrenci sayısı olarak fazla olduğu için A. Üniversitesi Açıköğretim Fakültesi öğrencileri ve diğer üniversitelerden başvurup kaydolan öğrenciler de bir başlık altında toplanmıştır.

Araştırmaya katılan öğretmen adaylarının kimlik bilgilerinin bazı bağımsız değişkenlere (cinsiyet, yaş ve kardeş sayısına) göre dağılımına Tablo 1'de yer verilmiştir.

Tablo 1. Katılımcıların cinsiyet, yaş ve kardeş sayısı değişkenlerine göre dağılımları

\begin{tabular}{llll}
\hline Değiş̧ken & Özellikler & F & \% \\
\hline \multirow{2}{*}{ Cinsiyet } & Kadın & 411 & 73,7 \\
& Erkek & 147 & 26,3 \\
\multirow{3}{*}{ Yaş Grupları } & 20-24 yaş arası & 389 & 69,7 \\
& 25-29 yaş arası & 103 & 18,5 \\
\multirow{2}{*}{ Kardeş Sayısı } & 30 ve üzeri & 66 & 11,8 \\
& 1-3 kardeş & 342 & 61,3 \\
& 4 ve üzeri & 207 & 37,1 \\
\hline
\end{tabular}

Tablo 1'de de görüldüğü gibi, son yıllarda öğretmenlik mesleğini yarım gün çalışabilme, uzun tatil dönemleri vb. gibi nedenlerden özellikle kadınlar $(\% 73,7)$ tercih etmektedirler. Araştırmaya katılan adayların \% 11,8'i 30 yaş ve üzerinde görülmektedir. 2011 yllından itibaren yoğun formasyon programı düzenlenmiş olmasına rağmen, 30 yaşın üzerinde adayın hala formasyon programına katıliyor olmasının nedeni dershanelerin kapatılmasından dolayı olabilir. Araştırmaya katılan 9 adayın kardeşi olmadığ1, \% 61,3'ünün 1-3 arasında kardeşi olduğu ve \% 37,1'inin de 4 ve üzerinde kardeşi olduğu ortaya çıkmıştır.

\section{Verilerin elde edilmesi}

Araştırma verileri öğretmen adaylarının kişisel bilgileri ile öğretmenlik mesleğine yönelik olarak sevme, değer verme ve uyum sağlama boyutlarına ilişkin tutumlarını belirlemeye yönelik hazırlanmış olan ölçek aracılığıyla toplanmıştır. Öğretmen adaylarının mesleğe karşı tutumları Çetin tarafından geliştirilen "Öğretmenlik Mesleği Tutum Ölçeğii" (Çetin, 2006) aracılığıyla belirlenmiştir. Çetin bu çalışmada kullanılan ölçeği Gazi Üniversitesi öğretmenlik programlarında okuyan 200 dördüncü sınıf 
öğrencisinden elde edilen verilerle 100 maddelik bir ölçek geliştirmiş ve 341 ögrenciye uygulamıştır. Denemeye tabi tutulan tutum cümleleri puanlandıktan sonra, iyi işlemeyen maddeleri seçmek için madde analizi yapılmıştır. Madde analizleri yapılan ölçekten iyi işlemeyen maddeler çıkarılmıştır. Öğretmenlik Mesleğine Yönelik Tutum Ölçeği'nin her bir alt faktör için güvenirliğin bir göstergesi olarak alfa iç tutarlık katsayısı ve bu kapsamda madde toplam korelasyonları hesaplanmıştır. Madde toplam korelasyonları 0.25 'in altında kalan ve eksi değere sahip maddeler ölçekten çıkarılmıştır. Temel bileşenler analizinde Kaiser-Meyer Olkin (KMO) değeri 95 bulunmuş ve Eigen değeri 1.00'den büyük olan maddeler ölçeğe alınmıştır. 35 maddeye düşürülen ve 15'i olumsuz 20'si olumlu olmak üzere 35 maddeden oluşan ölçek, öğretmenlik mesleğine ilişkin tutumları üç boyutta (sevgi, değer, uyum) ele almaktadır. Ters maddeler puanlanırken bilgisayarda gerekli düzenlemeler yapılmıştır.

\section{Verilerin çözümlenmesi}

Araştırmada elde edilen veriler uygun bir istatistik programı kullanılarak araştırma alt problemleri doğrultusunda çözümlenmeye çalışılmıştır. Çözümleme yapılırken betimsel istatistik tekniklerinden (yüzde, frekans, ortalama) ve değişkenler arasındaki farkların belirlenmesi aşamasında da t-testi ve Anova testi kullanılmıştır. Elde edilen sonuçlar araştırmanın alt problemleri çerçevesinde yorumlanmaya çalışılmıştır. Tutum puanları sinıflandırılırken aşağıdaki ölçütler çerçevesinde yapılmıştır:

$1,00-1,80$ Kesinlikle katılmıyorum

$1,81-2,60$ Katilmiyorum

2,61-3,40 Kararsizım

3,41-4,20 Katıliyorum

4,21 - 5,00 Tamamen katıllyorum

\section{Bulgular}

Bu bölümde araştırma bulguları çalışmanın alt problemleri dikkate alınarak sunulmuştur.

Araştırmanın birinci alt problemi, öğretmen adaylarının öğretmenlik mesleğine ilişkin tutumlarının nasıl olduğunu belirlemeye yöneliktir. Söz 
konusu tutumlar üç alt boyutta ele alınmıştır: öğretmenlik mesleğini sevme, öğretmenlik mesleğine değer verme ve öğretmenlik mesleğine uyum gösterme. Öğretmenlik mesleğine ilişkin tutumlar önce madde madde, daha sonra da birlikte ele alınmıştır. Aşağıdaki tabloda (Tablo 2) öğretmen adaylarının öğretmenlik mesleğini sevmelerine ilişkin tutum puanları yer almaktadır.

Tablo 2. Öğretmen adaylarının öğretmenlik mesleğini sevme boyutuna ilişkin tutumlar1

\begin{tabular}{|c|c|c|c|c|c|c|}
\hline TUTUM DAVRANIŞLARI & 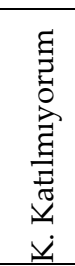 & 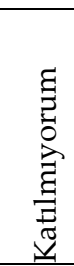 & 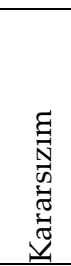 & 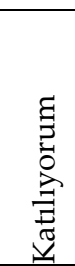 & 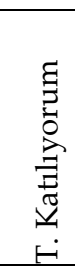 & 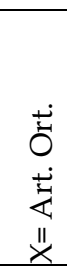 \\
\hline $\begin{array}{l}\text { 1. Benim için en ideal meslek öğretmen- } \\
\text { liktir. }\end{array}$ & 10 & 38 & 67 & 261 & 182 & 4,02 \\
\hline $\begin{array}{l}\text { 2. Bir ömür boyu öğretmenlik yapabili- } \\
\text { rim. }\end{array}$ & 17 & 46 & 135 & 213 & 147 & 3,77 \\
\hline $\begin{array}{l}\text { 3. Mesleğimle ilgili faaliyetleri yapmak } \\
\text { bana hiç zevk vermiyor. }{ }^{*}\end{array}$ & 6 & 23 & 38 & 239 & 252 & 4,27 \\
\hline 4. Öğretmenlik benim için bir tutkudur. & 6 & 63 & 124 & 239 & 126 & 3,75 \\
\hline $\begin{array}{l}\text { 5. Öğretmenliğin bence hiçbir cazip yanı } \\
\text { yoktur. * }\end{array}$ & 7 & 18 & 20 & 220 & 293 & 4,39 \\
\hline $\begin{array}{l}\text { 6. Öğretmenlik mesleğindeki tecrübem } \\
\text { arttıkça bu mesleğe daha çok bağlana- } \\
\text { cağıma inanıyorum. }\end{array}$ & 13 & 14 & 49 & 221 & 261 & 4,26 \\
\hline $\begin{array}{l}\text { 7. Bu mesleğin bana çok şey kazandıra- } \\
\text { cağın düşünmüyorum. * }\end{array}$ & 32 & 44 & 17 & 180 & 285 & 4,15 \\
\hline $\begin{array}{l}\text { 8. Öğretmenlikten alacağım manevi do- } \\
\text { yumu hiçbir şeye değişmem. }\end{array}$ & 12 & 75 & 82 & 242 & 147 & 3,78 \\
\hline $\begin{array}{l}\text { 9. Bu mesleği yapmaktan kimse beni alı- } \\
\text { koyamaz. }\end{array}$ & 10 & 107 & 129 & 207 & 105 & 3,52 \\
\hline $\begin{array}{l}\text { 10. Öğretmenliğin kişiliğime uygun bir } \\
\text { meslek olduğunu düşünmüyorum. }{ }^{*}\end{array}$ & 21 & 62 & 45 & 205 & 225 & 3,99 \\
\hline 11. Bu mesleği bilerek ve isteyerek seçtim. & 13 & 38 & 36 & 234 & 237 & 4,15 \\
\hline $\begin{array}{l}\text { 12. Öğretmenlikten alacağım hazzın bana } \\
\text { bu mesleğin tüm zorluklarını unuttu- } \\
\text { racağına inanıyorum. }\end{array}$ & 7 & 38 & 114 & 243 & 156 & 3,90 \\
\hline 13. Öğretmenlik mesleğini sevmiyorum. ${ }^{*}$ & 14 & 19 & 27 & 177 & 321 & 4,38 \\
\hline
\end{tabular}


Öğretmen Adaylarının Öğretmenlik Mesleğine İlişkin Tutumlarının Bazı Değişkenler Açısından İncelenmesi

\begin{tabular}{|c|c|c|c|c|c|c|}
\hline $\begin{array}{l}\text { 14. İnsanlara bir şeyler öğretmeyi sevdi- } \\
\text { ğim için bu mesleği seçtim. }\end{array}$ & 10 & 32 & 32 & 260 & 224 & 4,18 \\
\hline $\begin{array}{l}\text { 15. Benden yeni bir meslek seçmem is- } \\
\text { tense hiç tereddütsüz yine öğretmen- } \\
\text { lik mesleğini seçerdim. }\end{array}$ & 15 & 61 & 128 & 196 & 158 & 3,75 \\
\hline $\begin{array}{l}\text { 16. Bu meslekte her zaman öğrenme ve } \\
\text { öğretme heyecanı duyacağımı zannet- } \\
\text { miyorum. * }\end{array}$ & 9 & 39 & 82 & 236 & 192 & 4,01 \\
\hline $\begin{array}{l}\text { 17. İleride bu meslekte başarılı olabilmek } \\
\text { için çok çalışıyorum. }\end{array}$ & 4 & 56 & 66 & 285 & 147 & 3,92 \\
\hline $\begin{array}{l}\text { 18. Öğretmenlik mesleğinin beni ne } \\
\text { maddi nede manevi açıdan tatmin } \\
\text { edeceğini zannetmiyorum. }^{*}\end{array}$ & 7 & 25 & 37 & 223 & 266 & 4,28 \\
\hline $\begin{array}{l}\text { 19. Öğretmenlik mesleğini layıkıyla yapa- } \\
\text { cağıma inanıyorum. }\end{array}$ & 6 & 23 & 54 & 246 & 229 & 4,20 \\
\hline $\begin{array}{l}\text { 20. Ancak çok zorda kalırsam bu mesleği } \\
\text { yapmayı düşünebilirim. * }\end{array}$ & 7 & 34 & 28 & 222 & 267 & 4,34 \\
\hline $\begin{array}{l}\text { 21. Öğretmen olacağımı düşündükçe mut- } \\
\text { suz oluyorum. * }\end{array}$ & 8 & 16 & 26 & 179 & 329 & 4,44 \\
\hline $\begin{array}{l}\text { 22. Daha iyi bir meslek bulursam bir an } \\
\text { bile öğretmenlik yapacağımı zannet- } \\
\text { miyorum. * }\end{array}$ & 13 & 32 & 58 & 185 & 270 & 4,20 \\
\hline ORT A L A M A & & & & & & 4,08 \\
\hline
\end{tabular}

* Bu maddeler ters puanlanmıştır.

Yukarıdaki tablo incelendiğinde, öğretmen adaylarının mesleklerini sevdikleri söylenebilir. Öğretmen adaylarının öğretmenlik mesleğini sevme davranışları tutum puan ortalaması 4,08, yani "katılıyorum" düzeyinde bulunmuştur. Tutum puanı en düşük olan madde "Bu mesleği yapmaktan kimse beni alıkoyamaz." ( $\bar{X}=3,52$ - katılıyorum) davranışı olurken, "Öğretmen olacağımı düşündükçe mutsuz oluyorum." ( $\bar{X}=4,44$ - tamamen katılıyorum) maddesi en yüksek ortalama puana sahiptir.

Aşağıdaki tabloda (Tablo 3) öğretmen adaylarının öğretmenlik mesleğine değer verme boyutuna ilişkin tutum puanları yer almaktadır. 
Tablo 3. Öğretmen adaylarının öğretmenlik mesleğine değer verme boyutuna ilişkin tutumları

\begin{tabular}{|c|c|c|c|c|c|c|}
\hline TUTUM DAVRANIŞLARI & 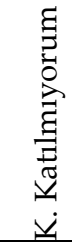 & 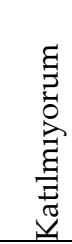 & 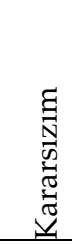 & 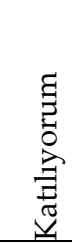 & 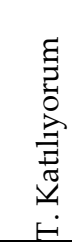 & 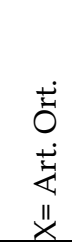 \\
\hline $\begin{array}{l}\text { 1. Öğretmenlik bilginin yanı sıra yete- } \\
\text { nek gerektiren bir meslektir. }\end{array}$ & 7 & 15 & 25 & 210 & 301 & 4,58 \\
\hline $\begin{array}{l}\text { 2. Ö̈̆gretmenlik paylaşımın en yoğun } \\
\text { yaşandığı bir meslektir. }\end{array}$ & 12 & 13 & 16 & 235 & 282 & 4,44 \\
\hline $\begin{array}{l}\text { 3. Bu mesleği öğrendikçe ciddiyetini } \\
\text { daha iyi anlıyorum. }\end{array}$ & 12 & 13 & 21 & 232 & 279 & 4,35 \\
\hline $\begin{array}{l}\text { 4. Öğretmenlik özveri isteyen bir mes- } \\
\text { lektir. }\end{array}$ & 12 & 11 & 5 & 203 & 327 & 4,47 \\
\hline 5. Öğretmenlik onurlu bir meslektir. & 10 & 13 & 13 & 161 & 361 & 4,61 \\
\hline $\begin{array}{l}\text { 6. Öğretmenlik mesleği hasta toplum- } \\
\text { ları kurtaracak bir ilaç gibidir. }\end{array}$ & 12 & 16 & 12 & 207 & 311 & 4,41 \\
\hline $\begin{array}{l}\text { 7. Öğretmenlik vicdani boyutu önemli } \\
\text { olan mesleklerin başında gelmekte- } \\
\text { dir. }\end{array}$ & 7 & 13 & 14 & 188 & 336 & 4,58 \\
\hline $\begin{array}{l}\text { 8. Öğretmenlik çok sabır isteyen bir } \\
\text { meslektir. }\end{array}$ & 13 & 8 & 6 & 167 & 363 & 4,61 \\
\hline OR T A L A M A & & & & & & 4,51 \\
\hline
\end{tabular}

Öğretmen adaylarının öğretmenlik mesleğine verdikleri değere ilişkin tutum puanları tablosu incelendiğinde, öğretmen adaylarının en yüksek oranda değer verdikleri davranışlar bu grupta yer almaktadır. Bu grupta yer alan en düşük puanın ( $\bar{X}=4,35$ - tamamen katılıyorum) "Bu mesleği öğrendikçe ciddiyetini daha iyi anlıyorum." davranışında olduğu, en yüksek puanın $(\bar{X}=4,61$ - tamamen katılıyorum) ise, "Öğretmenlik çok sabır isteyen bir meslektir." davranışında olduğu belirlenmiştir. Öğretmen adaylarının öğretmenlik mesleğine verdiği değer o mesleğe olan sevgilerinden daha yüksek bulunmuştur.

Aşağıdaki tabloda (Tablo 4) öğretmen adaylarının öğretmenlik mesleğine uyum gösterme boyutuna ilişkin tutum puanları yer almaktadır. 
Öğretmen Adaylarının Öğretmenlik Mesleğine İlişkin Tutumlarının Bazı Değişkenler Açısından İncelenmesi

Tablo 4. Öğretmen adaylarını öğretmenlik mesleğine uyum gösterme boyutuna ilişkin tutumları

TUTUM DAVRANIŞLARI

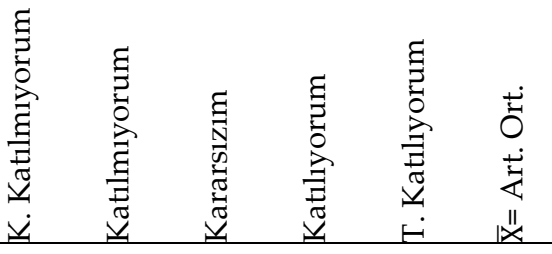

1. Derslerden ve öğretmenlerden biktığım için öğretmenlik benim için yapacağım mesleklerin en sonuncusu-

$\begin{array}{llllll}7 & 21 & 44 & 184 & 302 & 4,35\end{array}$
dur. *

2. Öğretmenlik gibi çileli bir mesleğe başlamaktan çekiniyorum. *

$\begin{array}{llllll}6 & 46 & 65 & 202 & 239 & 4,11\end{array}$

3. Sürekli kendini yenileme düşüncesi $\begin{array}{llllllll}\text { bu mesleği yapma konusunda beni } & 6 & 66 & 88 & 240 & 157 & 3,85\end{array}$ düşündürüyor. *

4. Öğretmenlik mesleği bir daha düzelmeyecek kadar yıpranmış bir mes19

18

57

242

222

4,13 lektir. *

5. Sürekli bir sınıfta hapsolmak beni sinirlendirir. *

* Bu maddeler ters puanlanmıştır.

Öğretmen adaylarının öğretmenlik mesleğine ilişkin uyum sağlama puan ortalaması 4,12, yani "katılıyorum" şeklinde bulunmuştur. Öğretmen adaylarının önemli bir kısmı kendini yenilemekten, çalışmaktan çekindiklerini ifade etmişlerdir. En düşük puan ( $\bar{X}=3,85$ - katıliyorum) "Sürekli kendini yenileme düşüncesi bu mesleği yapma konusunda beni düşündürüyor" davranışında ortaya çıkmıştır. "Derslerden ve öğretmenlerden bıktığım için öğretmenlik benim için yapacağım mesleklerin en sonuncusudur." düşüncesi öğretmen adaylarının hemen hemen hiç sahip olmadıkları bir duygu olarak tespit edilmiştir.

Aşağıdaki tabloda (Tablo 5) öğretmenlik mesleğine ilişkin tutumlar birlikte ele alınarak bulgular değerlendirilmeye çalışılmıştır. Öğretmen adaylarının tutum davranışlarının 3 boyutuna ilişkin değerleri gösteren Tablo 5 incelendiğinde, "Değer verme" boyutuna ait ortalamanın $(\bar{X}=4,61$; 
Tamamen katılıyorum) diğer iki boyuttan da daha yüksek olduğu görülmektedir.

Tablo 5. Öğretmen adaylarının öğretmenlik mesleğine ilişkin tutumları

\begin{tabular}{|c|c|c|c|c|c|c|}
\hline TUTUM DAVRANIŞLARI & 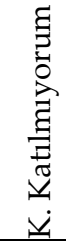 & 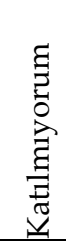 & 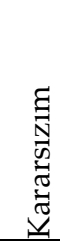 & 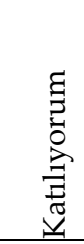 & 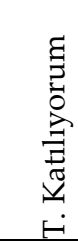 & 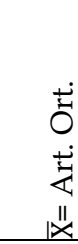 \\
\hline Sevgi Boyutu & 1 & 16 & 53 & 239 & 248 & 4,29 \\
\hline Değer Verme Boyutu & 8 & 9 & 12 & 134 & 395 & 4,61 \\
\hline Uyum Sağlama Boyutu & 4 & 15 & 74 & 214 & 251 & 4,24 \\
\hline
\end{tabular}

Sevgi ve uyum sağlama boyut ortalamaları arasında ciddi bir farklılık ortaya çıkmamıştır. Öğretmen adaylarının öğretmenlik mesleğine ilişkin tutumlarının o mesleği icra edebilmelerinin ön koşulu olarak beklenen düzeyde olduğu söylenebilir.

Araştırmanın ikinci alt problemi ise, çeşitli değişkenlere göre öğretmen adaylarının öğretmenlik mesleğine ilişkin tutumlarının farklılık gösterip göstermediğine ilişkindir. Aşağıdaki tabloda (Tablo 6) öğretmen adaylarının öğretmenlik mesleğine ilişkin tutumlarının cinsiyet değişkenine göre farkını gösteren $t$-testi sonuçlarına yer verilmiştir.

Tablo 6. Öğretmen adaylarnnı öğretmenlik mesleğine ilişkin tutumlarının cinsiyet değişkenine göre t-testi sonuçlarn

\begin{tabular}{lllllll}
\hline Değişken & Cinsiyet & $\mathbf{n}$ & $\overline{\mathbf{X}}$ & $\mathbf{s d}$ & $\mathbf{t}$ & $\mathbf{p}$ \\
\hline \multirow{2}{*}{ Sevgi } & Kadın & 411 & 4,12 &, 59 & \multirow{2}{*}{$7,66^{*}$} & \multirow{2}{*}{, 015} \\
& Erkek & 147 & 3,96 &, 71 & & \\
\multirow{2}{*}{ Değer } & Kadın & 411 & 4,55 &, 85 & \multirow{2}{*}{, 83} & \multirow{2}{*}{111} \\
& Erkek & 147 & 4,40 & 1,05 & & \\
\multirow{2}{*}{ Uyum } & Kadın & 411 & 4,41 &, 63 & \multirow{2}{*}{$3,61^{*}$} & \multirow{2}{*}{, 007} \\
& Erkek & 147 & 4,24 &, 80 & & \\
\hline
\end{tabular}

${ }^{*} \mathrm{p}<0,05$

Öğretmenlik mesleğine ilişkin tutumlar cinsiyet değişkenine göre incelendiğinde, öğretmenlik mesleğini sevme ve öğretmenlik mesleğine uyum gösterme tutum puanlarının öğretmen adaylarının cinsiyetlerine göre anlamlı farklılık ( $t=, 015$ ve, 007$)$ gösterdiği ortaya çıkmıştır. Her iki 
cinsiyete ait ortalamalar dikkate alındığında, kadın öğretmen adaylarının her iki boyutta da erkek öğretmen adaylarına göre daha yüksek ortalamaya $(4,12$ ve 4,41$)$ sahip olduğu görülmüştür. Öğretmenlik mesleğine değer verme maddelerine ilişkin öğretmen adaylarının tutumları cinsiyetlerine göre farklılık göstermemiştir. Necatibey Eğitim Fakültesi öğrencilerine yapılan bir çalışmada, öğrencilerin öğretmenlik mesleğine ilişkin tutumlarının cinsiyete göre anlamlı düzeyde farklılaştığ 1 gözlenmiştir (Terzi \& Tezci, Güz 2007).

Alanda yapılan çalışmalar incelendiğinde, öğrencilerin öğretmenlik mesleğine yönelik tutumlarının cinsiyete göre anlamlı düzeyde farklılaştı̆̆1 gözlenmiştir. Tablo 3'te de görüldüğ̈̈ gibi kız öğrencilerin öğretmenlik mesleğine ilişkin tutum puanlarının ortalaması erkek öğrencilerden daha yüksektir (t510=3.529, p<.05). Araştırmanın bu bulgusu Türkiye'de Öztürk ve ark. (2005), Çakır (2005), Kaya ve Büyükkasap (2005), Saracaloğlu ve ark. (2004) yaptıkları araştırmalardaki bulgularıyla paralellik göstermektedir. Aslında bu bulgu çok şaşırtıcı değildir. Öğretmenlik mesleğinin çalışma ve yaşam koşullarına ilişkin algılamalar, mesleğin kadınlara daha uygun olduğu yönündeki anlayışla paralellik göstermektedir. Coultas ve Levin (2002) yapmış oldukları araştırmada da farklı ülkelerde kadınların öğretmenlik mesleğini daha fazla tercih ettiklerine yönelik bulgular elde etmişlerdir.

Aşağıdaki tabloda (Tablo 7) öğretmen adaylarının yaşlarına göre öğretmenlik mesleğine ilişkin tutum puanları yer almaktadır.

Tablo 7. Öğretmen adaylarını öğretmenlik mesleğine ilişkin tutumlarıın yaşlarına göre t-testi sonuçları

\begin{tabular}{lllrlll}
\hline Değişken & Yaş Grupları & $\mathbf{N}$ & $\mathbf{\mathbf { X }}$ & $\mathbf{S d}$ & $\mathbf{F}$ & $\mathbf{t}$ \\
\hline \multirow{3}{*}{ Sevgi } & 20-24 yaş & 389 & 4,036 &, 640 & & \\
& 25-29 arası & 103 & 4,140 &, 612 & 2,753 & \multirow{2}{*}{065} \\
& 30 ve üzeri & 66 & 4,205 &, 552 & & \\
\multirow{2}{*}{ Değer } & 20-24 yaş & 389 & 4,497 &, 936 & & \\
& 25-29 arası & 103 & 4,551 &, 894 &, 144 & \multirow{2}{*}{, 866} \\
& 30 ve üzeri & 66 & 4,511 &, 738 & & \\
\multirow{3}{*}{ Uyum } & 20-24 yaş & 389 & 4,332 &, 693 & & \\
& 25-29 arasi & 103 & 4,415 &, 695 & 1,254 & \multirow{2}{*}{, 286} \\
& 30 ve üzeri & 66 & 4,452 &, 600 & & \\
\hline
\end{tabular}

${ }^{*} \mathrm{p}<0,05$ 
Tablo incelendiğinde, öğretmenlik mesleğini sevme, öğretmenlik mesleğine değer verme ve öğretmenlik mesleğine uyum gösterme tutumlarının yaşa göre farklılaşmadığı görülmüştür. Öğretmenlik mesleğini sevme boyutu ( $\mathrm{t}=, 065)$, anlamlı bir farklılaşma görülmemesine rağmen diğer iki boyuta göre $(t=, 866$ ve $t=, 286)$ yaşlar arasındaki farkın en yüksek olduğu boyuttur.

Aşağıdaki tabloda (Tablo 8) öğretmen adaylarının öğretmenlik mesleğine ilişkin tutumlarının eğitim gördükleri yükseköğretim kurumlarına göre farklılaşıp farklılaşmadığına ilişkin Kruskal Vallis testi sonuçları yer almaktadır.

Tablo 8. Öğretmen adaylarnnn eğitim gördükleri yükseköğretim kurumlarna göre tutum puanlarına ilişkin Kruskal-Vallis testi sonuçları

\begin{tabular}{|c|c|c|c|c|c|c|c|c|}
\hline $\begin{array}{l}\text { Tutum } \\
\text { Boyut- } \\
\text { lar1 }\end{array}$ & Üniversiteler & $\mathrm{N}$ & $\overline{\mathrm{X}}$ & $\mathrm{sd}$ & $\mathrm{X} 2$ & $\mathrm{p}$ & $\mathrm{z}$ & Fark \\
\hline Sevgi & $\begin{array}{l}\text { Devlet } \\
\text { (DÜ) } \\
\text { Öniversitesi } \\
\text { Özel } \\
\text { (ÖÜ) } \\
\text { Açıköğretim (AÖ) } \\
\begin{array}{l}\text { Diğer } \\
\text { (Dİ̈̈niversite }\end{array}\end{array}$ & $\begin{array}{l}425 \\
18 \\
55 \\
60\end{array}$ & 4,07 & 3 & 12,86 &, $005^{*}$ & $\begin{array}{l}-3,063 \\
-3,125 \\
-2,566\end{array}$ & $\begin{array}{l}\text { DÜ- } \\
\text { AÖ } \\
\text { ÖÜ- } \\
\text { AÖ } \\
\text { Dİ̈̈- } \\
\text { AÖ }\end{array}$ \\
\hline Değer & $\begin{array}{l}\text { Devlet Üniversitesi } \\
\text { Özel Üniversite } \\
\text { Açıköğretim } \\
\text { Diğer Üniversiteler }\end{array}$ & $\begin{array}{l}425 \\
18 \\
55 \\
60\end{array}$ & 4,46 & 3 & 5,54 & 137 & $-2,211$ & $\begin{array}{l}\text { DÜ- } \\
\text { AÖ }\end{array}$ \\
\hline Uyum & $\begin{array}{l}\text { Devlet Üniversitesi } \\
\text { Özel Üniversite } \\
\text { Açıöğretim } \\
\text { Diğer Üniversiteler }\end{array}$ & $\begin{array}{l}425 \\
18 \\
55 \\
60\end{array}$ & 4,13 & 3 & 9,96 & , $019^{*}$ & $\begin{array}{l}-3,049 \\
-2,262 \\
-2,014\end{array}$ & $\begin{array}{l}\text { DÜ- } \\
\text { AÖ } \\
\text { ÖÜ- } \\
\text { AÖ } \\
\text { Dİ̈̈- } \\
\text { AÖ }\end{array}$ \\
\hline
\end{tabular}

${ }^{*} \mathrm{p}<, 05$

Tablo 8 incelendiğinde, araştırma kapsamındaki üniversite öğrencilerinin sevgi $(X 2(3)=12.86 ; p<0,05)$ uyum $(X 2(3)=9.96 ; p<0,05)$ boyutundaki tutum puanları arasında istatistiksel olarak anlamlı bir farkın olduğu belir- 
lenmiştir. Söz konusu farkın hangi üniversite öğrencilerinin tutumlarından kaynaklandığını tespit etmek amacıyla yapılan ikili Mann-Whitney U karşılaştırmalarında, farklılığın "Sevgi" ve 'Uyum" boyutlarında Kayseri'deki devlet üniversitesi, özel üniversite ve diğer üniversiteler ile Açıöğretim öğrencilerinin tutum puanlarından kaynaklandığ 1 ortaya çıkmıştır. Öğrencilerin üniversitelerine göre tutum puan ortalamaları dikkate alındığında, bir üniversitenin Açıöğretim fakültesinde okuyan öğrencilerin tutum puanlarının her üç boyutta da (Sevgi: $\bar{X}=4,34$; Değer: 4,62; Uyum: $\bar{X}=4,41$ ) diğer üniversite öğrencilerinden daha yüksek olduğu görülmüştür.

Aşağıdaki tabloda (Tablo 8) öğretmen adaylarının öğretmenlik mesleğine ilişkin tutumlarının okudukları bölüm türüne göre farklılaşıp farklılaşmadığını gösteren $\mathrm{t}$-testi sonuçlarına yer verilmiştir.

Tablo 9. Öğretmen adaylarnın öğretmenlik mesleğine yönelik tutumlar ile okudukları bölüm türüne ilişkin t-testi sonuçları

\begin{tabular}{|c|c|c|c|c|c|c|c|}
\hline \multicolumn{2}{|c|}{ DeğişkenBölümler } & $\mathbf{N}$ & $\overline{\mathbf{X}}$ & SS & $\mathbf{t}$ & sd & $p$ \\
\hline \multirow{2}{*}{ Sevgi } & Sözel Bölümler & 507 & 4,09 & 621 & \multirow{2}{*}{1,652} & \multirow{2}{*}{556} & \multirow{2}{*}{,099 } \\
\hline & Sayısal Bölümler & 51 & 3,93 & 650 & & & \\
\hline \multirow{2}{*}{ Değer } & Sözel Bölümler & 507 & 4,46 & 726 & \multirow{2}{*}{,350 } & \multirow{2}{*}{556} & \multirow{2}{*}{,726 } \\
\hline & Sayısal Bölümler & 51 & 4,42 &, 507 & & & \\
\hline \multirow{2}{*}{ Uyum } & Sözel Bölümler & 507 & 4,13 & 704 & \multirow{2}{*}{,212 } & \multirow{2}{*}{556} & \multirow{2}{*}{833} \\
\hline & Sayısal Bölümler & 51 & 4,11 & ,726 & & & \\
\hline
\end{tabular}

${ }^{*} \mathrm{p}<0,05$

Öğretmenlik mesleğine ilişkin her üç boyuttaki tutum puanları öğrencilerin öğrenim gördükleri bölüm türüne - tipine (sözel / sayısal) göre incelendiğinde, Tablo 9'da da görüleceği gibi, tutum puanları ile bölümler arasında istatistiksel olarak anlamlı bir fark bulunmamıştır. Ancak ortalamalar dikkate alınarak bir karşılaştırma yapıldığında, sözel bölümlerde okuyan öğrencilerin her üç boyuttaki tutum puanlarının sayısal bölümlerde okuyan öğrencilerin tutum puanlarından daha yüksek olduğu görülmektedir.

Aşağıdaki tabloda (Tablo 10) öğretmen adaylarının öğretmenlik mesleğine ilişkin tutumlarının mezuniyet durumlarına göre farklılaşıp farklılaşmadığını gösteren t-testi sonuçları yer almaktadır. 
Öğretmenlik mesleğine ilişkin tutumlar mezuniyet değişkenine göre incelendiğinde, öğrencilerin mezun olmuş olmaları ile 4. sınıfta öğrenim görmeye devam ediyor olmaları arasında anlamlı farklılık görülmemiştir.

Tablo 10. Öğretmen adaylarının öğretmenlik mesleğine yönelik tutumlarn ile mezuniyet durumlarına ilişkin t-testi sonuçlarn

\begin{tabular}{llllllll}
\hline Değişken & Mezuniyet & $\mathbf{N}$ & $\overline{\mathbf{X}}$ & SS & $\mathbf{t}$ & sd & $\mathbf{p}$ \\
\hline \multirow{2}{*}{ Sevgi } & Mezun & 119 & 4,04 &, 628 & \multirow{2}{*}{, 528} & \multirow{2}{*}{556} & \multirow{2}{*}{598} \\
& 4. Sinıf & 439 & 4,08 &, 624 &, 528 & & \\
\multirow{2}{*}{ Değer } & Mezun & 119 & 4,39 &, 752 & $-1,244$ & 556 & \multirow{2}{*}{214} \\
& 4. Sinıf & 439 & 4,48 &, 696 & & & \\
\multirow{2}{*}{ Uyum } & Mezun & 119 & 4,20 &, 728 & \multirow{2}{*}{1,354} & 556 & \multirow{2}{*}{176} \\
& 4. Sinıf & 439 & 4,10 &, 698 & & & \\
\hline
\end{tabular}

${ }^{*} \mathrm{p}<0,05$

Sadece Sevgi ve Değer boyutunda 4. Sınıflar lehine, Uyum boyutunda da mezun öğrenciler lehine küçük bir ortalama farkı ortaya çımıştır.

Aşağıdaki tabloda (Tablo 11) öğretmen adaylarının öğretmenlik mesleğine yönelik tutumlarının babalarının mesleğine göre farklılaşıp farklılaşmadığını gösteren anova testi sonuçları bulunmaktadır.

Tablo 11. Öğretmen adaylarının öğretmenlik mesleğine yönelik tutumlarn ile baba mesleklerine ilişkin Kruskal-Wallis testi sonuçları

\begin{tabular}{|c|c|c|c|c|c|c|c|c|}
\hline Değişken & $\begin{array}{l}\text { Babanın } \\
\text { neği }\end{array}$ & $-\mathbf{N}$ & & $\overline{\mathbf{X}}$ & SS & sd & $\mathrm{X} 2$ & $\mathrm{p}$ \\
\hline & İşçi & 90 & 4,16 & & & & & \\
\hline & Serbest Meslek & 180 & 4,03 & & & & & \\
\hline \multirow[t]{5}{*}{ Sevgi } & Memur & 92 & 3,98 & 4,07 & 624 & 4 & 5,392 & 249 \\
\hline & Emekli & 181 & 4,11 & & & & & \\
\hline & Vefat & 15 & 4,03 & & & & & \\
\hline & İşçi & 90 & 4,53 & & & & & \\
\hline & Serbest Meslek & 180 & 4,39 & & & & & \\
\hline \multirow[t]{5}{*}{ Değer } & Memur & 92 & 4,41 & 4,46 & ,709 & 4 & 8,221 & ,084 \\
\hline & Emekli & 181 & 4,52 & & & & & \\
\hline & Vefat & 15 & 4,39 & & & & & \\
\hline & İşçi & 90 & 4,14 & & & & & \\
\hline & Serbest Meslek & 180 & 4,09 & & & & & \\
\hline \multirow[t]{3}{*}{ Uyum } & Memur & 92 & 4,12 & 4,13 & 705 & 4 & 1,624 & 805 \\
\hline & Emekli & 181 & 4,17 & & & & & \\
\hline & Vefat & 15 & 3,95 & & & & & \\
\hline
\end{tabular}

${ }^{*} \mathrm{p}<0,05$ 
Tablo 11'de de görüldüğü gibi, öğretmen adaylarının babalarının mesleklerinin, adayların öğretmenlik mesleğini sevme, mesleğe değer verme ve uyum göstermeleri üzerinde etkisi bulunmamıştır. Tüm boyutlarda ortalamalar incelendiğinde babası işçi ya da serbest meslek sahibi olan öğrencilerin tutum puanlarının her üç boyutta da yüksek olduğu gözlenmiştir.

Aşağıdaki tabloda (Tablo 12) öğretmen adaylarının öğretmenlik mesleğine yönelik tutumlarının anne mesleklerine göre farklılaşıp farklılaşmadığını gösteren Kruskal-Vallis testi sonuçlarına yer verilmiştir.

Tablo 12. Öğretmen adaylarının öğretmenlik mesleğine yönelik tutumları ile anne mesleklerine ilişkin Kruskal-Wallis testi sonuçları

\begin{tabular}{|c|c|c|c|c|c|c|c|c|}
\hline \multicolumn{2}{|c|}{ DeğişkenAnnenin Mesleği } & \multicolumn{2}{|l|}{$\mathbf{N}$} & \multirow[t]{2}{*}{$\overline{\mathbf{X}}$} & \multirow[t]{2}{*}{ SS } & \multirow[t]{2}{*}{ sd } & \multirow[t]{2}{*}{$\mathrm{X} 2$} & \multirow[t]{2}{*}{ p } \\
\hline \multirow{6}{*}{ Sevgi } & Ev kadını - İşsiz & 520 & 4,07 & & & & & \\
\hline & Serbest Meslek & 12 & 4,16 & \multirow{5}{*}{4,07} & \multirow{5}{*}{,624 } & \multirow{5}{*}{5} & \multirow{5}{*}{2,48} & \multirow{5}{*}{ 780 } \\
\hline & Memur & 12 & 3,95 & & & & & \\
\hline & İşçi & 4 & 4,33 & & & & & \\
\hline & Emekli & 9 & 4,03 & & & & & \\
\hline & Vefat & 1 & 4,59 & & & & & \\
\hline \multirow{6}{*}{ Değer } & Ev kadını - İşsiz & 520 & 4,45 & \multirow{6}{*}{4,46} & \multirow{6}{*}{,709 } & \multirow{6}{*}{5} & \multirow{6}{*}{6,79} & \multirow{6}{*}{,237 } \\
\hline & Serbest Meslek & 12 & 4,74 & & & & & \\
\hline & Memur & 12 & 4,41 & & & & & \\
\hline & İşçi & 4 & 4,34 & & & & & \\
\hline & Emekli & 9 & 4,53 & & & & & \\
\hline & Vefat & 1 & 4,88 & & & & & \\
\hline \multirow{6}{*}{ Uyum } & Ev kadını - İşsiz & 520 & 4,12 & \multirow{6}{*}{4,13} & \multirow{6}{*}{,705 } & \multirow{6}{*}{5} & \multirow{6}{*}{ 651 } & \multirow{6}{*}{,986 } \\
\hline & Serbest Meslek & 12 & 4,28 & & & & & \\
\hline & Memur & 12 & 4,15 & & & & & \\
\hline & İşçi & 4 & 4,20 & & & & & \\
\hline & Emekli & 9 & 4,24 & & & & & \\
\hline & Vefat & 1 & 4,40 & & & & & \\
\hline
\end{tabular}

${ }^{*} \mathrm{p}<0,05$

Öğretmenlik mesleğine yönelik tutumlar anne mesleği değişkenine göre incelendiğinde, serbest meslek sahibi anneler ile ev kadını olan annelerin tutum puanları diğer meslek sahibi annelere göre daha yüksek görülmektedir ancak anne mesleğine göre tutum puanları arasında istatistiksel bir farklılık ortaya çıkmamıştır. 
Aşağıdaki tabloda (Tablo 13) öğretmen adaylarının öğretmenlik mesleğine yönelik tutumlarının adayların kardeş sayılarına göre farklılaşıp farklılaşmadığının gösteren $\mathrm{t}$-testi sonuçları yer almaktadır.

Tablo 13. Öğretmen adaylarnnın öğretmenlik mesleğine yönelik tutumlarn ile kardeş sayılarına ilişkin t-testi sonuçları

\begin{tabular}{|c|c|c|c|c|c|c|}
\hline Değişken & $\begin{array}{l}\text { Kardeş } \\
\text { Sayısı } \\
\end{array}$ & $\mathbf{N}$ & $\overline{\mathbf{X}}$ & sd & $\mathbf{F}$ & $\mathbf{t}$ \\
\hline \multirow{2}{*}{ Sevgi } & $1-3$ aras 1 & 342 & 4,071 & 653 & \multirow{2}{*}{3,349} & \multirow{2}{*}{849} \\
\hline & 4 ve üzeri & 207 & 4,081 & ,586 & & \\
\hline \multirow{2}{*}{ Değer } & $1-3$ arası & 342 & 4,498 & 849 & \multirow{2}{*}{,453 } & \multirow{2}{*}{,639 } \\
\hline & 4 ve üzeri & 207 & 4,534 & 999 & & \\
\hline \multirow{2}{*}{ Uyum } & $1-3$ aras 1 & 342 & 4,346 & 660 & \multirow{2}{*}{,002 } & \multirow{2}{*}{,476 } \\
\hline & 4 ve üzeri & 207 & 4,390 & ,727 & & \\
\hline
\end{tabular}

${ }^{*} \mathrm{p}<0,05$

Öğretmenlik mesleğine yönelik tutumlar kardeş sayısı değişkenine göre incelendiğinde, kardeş sayısı 1-3 arasında olan adaylarla kardeş sayısı 4 ve üzeri olan adaylar arasında bir farklılık görülmemiştir.

Aşağıdaki tabloda (Tablo 14) öğretmen adaylarının öğretmenlik mesleğine yönelik tutumlarının ailelerinde öğretmen bulunması durumuna göre farklılaşıp farklılaşmadığını gösteren t-testi sonuçlarına yer verilmiştir.

Tablo 14. Öğretmen adaylarını öğretmenlik mesleğine yönelik tutumlar ile ailelerinde öğretmen bulunma durumlarna ilişkin t-testi sonuçları

\begin{tabular}{lclllll}
\hline \multirow{2}{*}{ Değişken } & $\begin{array}{c}\text { Ailede } \\
\text { Öğretmen }\end{array}$ & $\mathbf{N}$ & $\overline{\mathbf{X}}$ & $\mathbf{s d}$ & $\mathbf{F}$ & $\mathbf{t}$ \\
\hline \multirow{2}{*}{ Sevgi } & Var & 170 & 4,066 &, 631 & \multirow{2}{*}{, 042} & \multirow{2}{*}{, 828} \\
& Yok & 388 & 4,079 &, 627 & & \\
\multirow{2}{*}{ Değer } & Var & 170 & 4,491 &, 958 & \multirow{2}{*}{, 441} & \multirow{2}{*}{, 770} \\
& Yok & 388 & 4,516 &, 883 & & \\
\multirow{2}{*}{ Uyum } & Var & 170 & 4,363 &, 703 & \multirow{2}{*}{, 049} &, 974 \\
\hline
\end{tabular}

${ }^{*} \mathrm{p}<0,05$

Tablo 13'te de görüldüğü gibi ailelerinde öğretmen bulunan adaylar ile bulunmayan adayların mesleği sevme, mesleğe değer verme ve uyum gösterme tutum puan ortalamaları birbirine oldukça yakın bulunmuştur. Bu da sevgi, değer ve uyum boyutları açışından ailede öğretmen bulunma 
ve bulunmama durumları arasında bir farklılık olmadığını göstermektedir.

\section{Sonuç, Tartışma ve Öneriler}

$\mathrm{Bu}$ bölümde, eğitim fakülteleri dışından gelen öğretmen adaylarının öğretmenlik mesleğine ilişkin tutumlarını betimlemeye yönelik yapılan bu çalışmada elde edilen bulgulardan çıkarılan sonuç, tartışma ve öneriler kısmına yer verilmiştir. Araştırma sonuçları aşağıdaki sorular çerçevesinde ele alınmıştır: Öğretmen adaylarının öğretmenlik mesleğine ilişkin tutumları nasıldır? Öğretmen adaylarının öğretmenlik mesleğine ilişkin tutumlarının onların, cinsiyetlerine, yaşlarına, geldikleri üniversiteye, okudukları bölüme, mezun olup olmamalarına, babalarının mesleklerine, annelerinin mesleklerine, aile tiplerine ve ailelerinde öğretmen olup olmamasına göre değişmekte midir? Öğretmen adaylarının öğretmenlik mesleğinin sevgi, değer ve uyum boyutlarına ilişkin tutumları arasında anlamlı bir fark var mıdır?

Araştırma verilerinin çözümlenmesi sonucunda, öğretmen adaylarının mesleklerini sevdikleri ortaya çıkmıştır. Yine aynı grubun mesleğine değer verme puanları sevgi puanlarından daha yüksek bulunmuştur. $\mathrm{Bu}$ da aday öğretmenlerin mesleğin önemini anladıkları sonucunu ortaya koyuyor. Öğretmen adayları, kendilerinin bu mesleğe çok uyum sağlayabileceklerini ifade etmişlerdir. Bu boyutta en sıkıntılı durum ise, öğretmen adaylarının kendilerini yenilemekten kaçındıklarının ortaya çıkmasıdır. Alanda yapılan çalışmalar (Özder, Konedralı, ve Zeki, 2010; Başbay, Ünver,ve Nilay, 2009; Demircioğlu ve Özdemir, 2014; Güçlü ve Bozgeyikli, 2016; Terzi ve Tezci, Güz 2007; Can ve Bahar, 2010) öğretmenlerin ya da öğretmen adaylarının mesleklerini sevdikleri sonucunu ortaya çıkarmıştır. Öğretmenlik mesleğini öğretmenlerin sevmeleri, o mesleğe sayg1 göstermeleri meslekte başarılı olabilmeleri için ön koşullardan birisi olarak düşünülebilir. Öğretmenlik mesleğine yönelik tutumlarda etkili olan unsurun ne olduğunu belirlemek ve gerektiğinde buna ilişkin ek etkinlikler düzenleyebilmek için bu tür çalışmaların her yıl değişik sinıflarda yapılmasında yarar vardır. Böylece öğretmen yetiştiren fakültelerde öğretmen adaylarına öğretmenlik mesleğine ilişkin kazandırılan duyuşsal davranışların düzeyi belirlenmiş olabilir. 
Öğretmen adaylarının öğretmenlik mesleğini sevmeleri ve kendilerini bu mesleğe uygun görmeleri ile öğretmen adaylarının cinsiyetleri arasında farklılık ortaya çıkmıştır. Kadın öğretmen adayları öğretmenlik mesleğine kendilerini daha yakın bulmakta ve erkek adaylara oranla mesleği daha çok sevmektedirler. Elde edilen bu sonuç alanda yapılan bazı çalışmalarla (Terzi ve Tezci, Güz 2007; Ekici, 2014; Gökçe ve Sezer, 2012) paralellik gösterirken bazı çalışmalarla (Özder vd., 2010; Çapa ve Çil, 2000; Bademcioğlu, Karataş, ve Alc1, 2014) da örtüşmemektedir. Öğretmenlik mesleğinin çalışma koşulları kadın öğretmen adaylarını daha çok isteklendirmektedir. Cinsiyetler arasında farklılığın ortaya çıkmadığ 1 araştırmalarda ise, alt boyutlarda farklılıklar görülmektedir. Yani kadın öğretmen adayları genel anlamda daha fazla mesleğe ilgi göstermekte ancak birkaç alt boyutta (örneğin kendine güven alt boyutu gibi) erkek öğretmen adaylarının puanları daha yüksek bulunduğundan ortalamalar arasında farklılık bulunmamıştır. Erkeklerin öğretmenlik mesleğini giderek neden tercih etmedikleri konusunda yeni araştırmaların yapılması, öğretmenlik mesleğinin sadece kadın mesleği olarak algılanmaması açısından önemlidir.

Öğretmen adaylarının yaşları ile öğretmenlik mesleğine ilişkin tutumları arasında anlamlı farklılık ortaya çıkmamıştır. Alanyazın incelendiğinde öğretmen adaylarının öğretmenlik mesleğine yönelik tutumları ile yaşları arasında farklılık olup olmadığına dair çok fazla araştırmaya rastlanmamaktadır. Ancak Ekici (2014)'nin bulguları da öğretmenlik mesleğine yönelik tutumlar ile yaş arasında anlamlı bir farklılık olmadığını destekler niteliktedir. Bu da tüm yaş gruplarının öğretmenlikle ilgili ortak bir algıya sahip olduğu ve yaşın bir belirleyici olmadığı şeklinde yorumlanabilir.

Öğretmen adaylarının öğretmenlik mesleğine ilişkin tutumlarının öğrenim gördükleri üniversiteye göre değişip değişmediğini ortaya koyan bulgulara göre, Anadolu Üniversitesi (açıköğretim) öğrencilerinin öğretmenlik mesleğini diğerlerine göre daha çok sevdikleri, değer verdikleri ve mesleğe kendilerini daha yakın gördükleri sonucunu ortaya çıkarmıştır. Söz konusu sonucun çıkmasının nedeni, açık öğretim öğrencilerinin öğretmen olma olasılıklarının diğer üniversitelerde öğrenim gören öğrencilere göre daha zor olmasından kaynaklanmış olabilir. Alanda yapılan bazı 
çalışmalar incelendiğinde ise öğretmen adaylarının öğretmenlik mesleğine ilişkin tutumlarının öğrenim gördükleri üniversiteye göre farklılaştığ1 bulgusu Tekerek ve Polat (2011)'ın bulgularıyla paralellik gösterirken Bulut (2009) ve Ekici (2014)'nin bulgularıla farklılaşma göstermiştir.

Öğretmenlik mesleğine ilişkin tutumlar ile öğretmen adaylarının öğrenim gördükleri bölümler arasında anlamlı fark bulunmamıştır. Alanyazın incelendiğinde elde edilen bu sonuç bazı çalışmalarla (Bademcioğlu vd., 2014; Tekerek ve Polat, 2011) paralellik gösterirken bazı çalışmalarla da (Terzi ve Tezci, Güz 2007; Bulut, 2009; Ekici, 2014) örtüşmemektedir. Yine aynı şekilde öğretmenlik mesleğine ilişkin tutumlar ile öğretmen adaylarının mezun olmaları ya da hala okuyor olmaları arasında anlamlı fark ortaya çıkmamıştır. Bu bulgunun aksine Bademcioğlu vd. (2014) deneyimli öğretmenler lehine anlamlı bir farklılık olduğu sonucuna ulaşmıştır. Öğretmenlik deneyiminin öğretmen adaylarının öğretmenlik mesleğine yönelik tutumları üzerinde olumlu ve önemli bir etkiye sahip olduğunu belirtmişlerdir. Tural ve Kabadayı (2014) ise mezun olmuş ve olmamış öğrenci tutumlarının öğretmenliği sevme boyutunda mezun olmuşlar lehine bir farklılaşma gösterdiğini belirtirken mesleğe değer verme ve uyum sağlama boyutlarında bir farklılaşma göstermediğini belirtmiştir. Öğretmen adaylarının baba ve anne mesleklerinin onların öğretmenlik mesleğine ilişkin tutumlarını etkileyip etkilemediğine ilişkin yapılan test sonucunda da adayların tutumlarının onların ebeveynlerinin mesleklerine göre değişmediği görülmüştür. Sadece annesi serbest meslek sahibi olan adayların öğretmenlik mesleğine ilişkin tutumları ile diğer meslekler arasında anlamlı fark ortaya çıkmıştır. Çocuğun yetişmesindeki en etkili bireyin anne olduğu varsayılırsa, söz konusu annelerin mesleklerinden dolayı çevreyi daha iyi tanıdıkları ve kendi deneyimlerinin sonucunda çocuklarına öğretmenlik mesleğini önerdikleri düşünülebilir. Bu bulgulara paralel olarak Tekerek ve Polat (2011) öğretmen adaylarının baba öğrenim durumu ile öğretmenlik mesleğine yönelik tutumları arasında anlamlı bir farklılık görülmediği bulgusuna ulaşmışlardır. Ancak öğretmen adaylarının anne öğrenim durumlarını incelediklerinde anneleri ilkokul ve lise mezunu olan öğretmen adaylarının anneleri ortaokul mezun olan öğretmen adaylarından daha olumlu tutum geliştirdikleri sonucuna varmışlardır. Evdeki kardeş sayısının adayların tutumlarında 
etkili olmadığı görülmüştür. Alanyazın incelemesi sonucunda da bu değişkenle ilgili verilere rastlanmamıştır.

\section{Sonuçlar}

Araştırmanın alt problemleri doğrultusunda aşağıdaki sonuçlara ulaşılmıştır.

Öğretmen adayları öğretmenlik mesleğini sevme boyutuna ilişkin olarak yeterli düzeyde puan almışlardır.

Öğretmen adayları öğretmenlik mesleğine ilişkin tutumlardan mesleğe değer verme boyutunda en yüksek tutum puanını almışlardır.

Öğretmen adayları mesleğe uyum sağlama boyutunda en düşük puanı almışlardır.

Öğretmenlik mesleğini sevme ve uyum sağlama boyutlarına ilişkin tutum puanları öğretmen adaylarının cinsiyetlerine göre farklılaşmaktadır.

Öğretmen adaylarının öğretmenlik mesleğine ilişkin tutum puanları öğrenim gördükleri / mezun oldukları üniversiteye göre farklılık göstermektedir. Açıöğretim Fakültesi öğrencileri ile diğer üniversitelerde okuyan öğrencilerin tutum puanları arasında farklılık meydana gelmiştir. Araştırmanın en önemli sonucu, Açıöğretim Fakültesi öğrencilerinin öğretmenlik mesleğine diğer öğrenci gruplarından daha çok önem vermeleridir.

Öğretmen adaylarının öğretmenlik mesleğine ilişkin tutum puanları araştırmanın diğer değişkenlerine göre farklılık göstermemektedir.

Öneriler

Öğretmen adaylarının mesleğe uyum sağlamalarını daha üst düzeye çıkarabilmek amacıyla uygulama ağırlıklı derslerin süreleri artırılabilir.

$\mathrm{Bu}$ araştırmanın bir sonucu olarak da özellikle kadın adaylar öğretmenlik mesleğini daha çok tercih eder hale gelmiştir. Öğretmenlik mesleği erkekler için de cazibeli bir meslek haline getirilmelidir. Bu bağlamda meslek seçimi sürecinde yönlendirmelere ağırlık verilebilir. Ayrıca öğretmenlik mesleğinin icrası sürecinde meslekte yükselme ölçütleri getirilerek, öğretmenlerin hem maddi hem bilimsel düzeyi artırılabilir.

Araştırma sonuçlarında elde edilen bulguların mesleğin icra edilmesi sürecinde de izlenmesi ve gerekli alıştırmaların yapılması, eğitim sürecinin etkililiğini artırmak için yararlı olabilir. 
Öğretmen Adaylarının Öğretmenlik Mesleğine İlişkin Tutumlarının Bazı Değişkenler Açısından İncelenmesi

\section{Kaynakça}

Bademcioğlu, M., Karataş, H. ve Alc1, B. (2014). The investigation of teacher candidates' attitudes towards teaching profession (Öğretmen adaylarının öğretmenlik mesleğine ilişkin tutumlarına yönelik inceleme. Educational Research Association - The International Journal of Educational Researchers, 5(2), 16-29.

Başbay, M., Ünver, G. ve Nilay., T. B. (2009). Ortaöğretim alan öğretmenliği tezsiz yüksek lisans öğrencilerinin öğretmenlik mesleğine yönelik tutumları: boylamsal bir çalışma. Educational Administration: Theory and Practice - Kuram ve Uygulamada Eğitim Yönetimi, 15(59), 345-366.

Can, Ş. (Bahar 2010). Tezsiz yüksek lisans öğrencilerinin öğretmenlik mesleğine yönelik tutumları. Muğla Üniversitesi Sosyal Bilimler Enstitüsü Dergisi (ILKE), 24, 13-28.

Cobb, V. L. (1999, 11). An international comparison of teacher education. Eric Digests: http://www.ericdigests.org/2000-3/teacher.htm Erişim tarihi: 13 Ocak 2016.

Çapa, Y. ve Çil, N. (2000). Öğretmen adaylarının öğretmenlik mesleğine yönelik tutumlarının farklı değişkenler açısından incelenmesi. Hacettepe Üniversitesi Ĕ̆itim Fakültesi Dergisi, 18, 69-73.

Çetin, Ş. (2006). Öğretmenlik Mesleği Tutum Ölçeğinin Geliştirilmesi Geçerlik ve Güvenirlik Çalışması. Gazi Üniversitesi Endüstriyel Sanatlar Eğitim Fakültesi Dergisi(18), 28-37.

Demircioğlu, E. ve Özdemir, M. (2014). Fen ve edebiyat fakültesi öğrencilerinin öğretmenlik mesleğine yönelik tutumlarının çeşitli değişkenlere göre incelenmesi. Mersin Üniversitesi Eğitim Fakültesi Dergisi, 10(3), 110-122.

Durmuşçelebi, M. (2015). Öğretmenlik eğitimi programının etkililiği. Pegem Ĕ̈itim ve Ö̆̆retim Dergisi, 5(5), 747-766.

Ekici, F. Y. (2014). Öğretmen adaylarının öğretmenlik mesleğine yönelik tutumlarının çeşitli değişkenler açısından incelenmesi (İstanbul Sabahattin Zaim Üniversitesi Örneği). Uluslararası Sosyal Araştırmalar Dergisi - The Journal of International Social Research, 7(35), 658-665. 
Gökçe, F. ve Sezer, G. O. (2012). Öğretmen adaylarının öğretmenlik mesleğine yönelik tutumları (Uludağ Üniversitesi Örneği). Uludă̆ Üniversitesi Ĕ̆itim Fakültesi Dergisi, 25(1), 1-23.

Güçlü, M. ve Bozgeyikli, H. (2016) Öğretmen adaylarının Türk Eğitim Tarihi dersine yönelik Tutumlarının incelenmesi, Journal of History School, 9(25), 401-415.

Harris, A. (2000). What works in school improvement? Lesson from the field and future directions. Educational Research, 1-11.

Karagözoğlu, G. (1987). Yükseköğretime geçişte öğretmenlik mesleğine yönelme. Hacettepe Üniversitesi Eğitim Fakültesi Dergisi(2), 35-46.

Katkat, D. ve Mızrak, O. (2003). Öğretmen adaylarının pedagojik eğitimlerinin problem çözme becerilerine etkisi. Milli Ĕ̆itim Dergisi(158).

Kavcar, C. (2002). Cumhuriyet döneminde dal öğretmeni yetiştirme. Ankara Üniversitesi Ĕ̆itim Bilimleri Fakültesi Dergisi, 35(1-2), 1-14.

Özder, H., Konedralı, G.ve Zeki, C. P. (2010). Öğretmen adaylarının öğretmenlik mesleğine yönelik tutumlarının çeşitli değişkenler açısından incelenmesi. Educational Administration: Theory and Practice Kuram ve Uygulamada Ĕ̆itim Yönetimi, 16(2), 253-275.

Tekerek, M. ve Polat, S. (2011). Öğretmen adaylarının öğretmenlik mesleğine ilişkin tutumları. 5th International Computer \&Instructional Technologies Symposium, 22-24 September 2011, Furat University, Elaziğ-Turkey.

Terzi, A. ve Tezci, E. (Güz 2007). Necatibey Eğitim Fakültesi öğrencilerinin öğretmenlik mesleğine ilişkin tutumları. Educational Administration: Theory and Practice - Kuram ve Uygulamada Eğitim Yönetimi(52), 593-614.

Tural, G. ve Kabadayı, Ö. (2014). Pedagogical formation program teacher candidates' attitudes towards the teaching profession. Anadolu Journal of Education Sciences International, 4(1),1-12.

Yüksek Öğretim Kurumu. (1998). Eğitim fakülteleri öğretmen yetiştirme programlarının yeniden düzenlenmesi. YÖK: www.yok.gov.tr/egitim/ogretmen_yetistirme_lisans/rapor.pdf Erişim tarihi: 1 Mart 2016. 
Öğretmen Adaylarının Öğretmenlik Mesleğine İlişkin Tutumlarının Bazı Değişkenler Açısından İncelenmesi

\section{Kaynakça Bilgisi / Citation Information}

Durmuşçelebi, M., Yıldız, N. \& Saygı, E. (2017). Öğretmen Adaylarının Öğretmenlik Mesleğine İlişkin Tutumlarının Bazı Değişkenler Açısından İncelenmesi, OPUS - Uluslararası Toplum Araştırmaları Dergisi, $7(12), 8-32$. 